\title{
Article \\ Simulation of Carbon Exchange from a Permafrost Peatland in the Great Hing'an Mountains Based on CoupModel
}

\author{
Yue $\mathrm{Li}^{1,2}$, Zhongmei Wan ${ }^{1, *(1)}$ and Li Sun ${ }^{2, *}$ \\ 1 College of Earth Sciences, Jilin University, Changchun 130061, China; yli18@mails.jlu.edu.cn \\ 2 Key Laboratory of Wetland Ecology and Environment, Northeast Institute of Geography and Agroecology, \\ Chinese Academy of Sciences, Changchun 130102, China \\ * Correspondence: wanzm@jlu.edu.cn (Z.W.); sunli@iga.ac.cn (L.S.)
}

Citation: Li, Y.; Wan, Z.; Sun, L. Simulation of Carbon Exchange from a Permafrost Peatland in the Great

Hing'an Mountains Based on

CoupModel. Atmosphere 2022, 13, 44. https://doi.org/10.3390/

atmos13010044

Academic Editor: Sergey

N. Vorobyev

Received: 14 October 2021

Accepted: 21 December 2021

Published: 28 December 2021

Publisher's Note: MDPI stays neutral with regard to jurisdictional claims in published maps and institutional affiliations.

Copyright: (C) 2021 by the authors. Licensee MDPI, Basel, Switzerland. This article is an open access article distributed under the terms and conditions of the Creative Commons Attribution (CC BY) license (https:// creativecommons.org/licenses/by/ $4.0 /)$.

\begin{abstract}
Climate change is accelerating its impact on northern ecosystems. Northern peatlands store a considerable amount of $C$, but their response to climate change remains highly uncertain. In order to explore the feedback of a peatland in the Great Hing'an Mountains to future climate change, we simulated the response of the overall net ecosystem exchange (NEE), ecosystem respiration (ER), and gross primary production (GPP) during 2020-2100 under three representative concentration pathways (RCP2.6, RCP6.0, and RCP8.5). Under the RCP2.6 and RCP6.0 scenarios, the carbon sink will increase slightly until 2100. Under the RCP8.5 scenario, the carbon sink will follow a trend of gradual decrease after 2053. These results show that when meteorological factors, especially temperature, reach a certain degree, the carbon source/sink of the peatland ecosystem will be converted. In general, although the peatland will remain a carbon sink until the end of the 21st century, carbon sinks will decrease under the influence of climate change. Our results indicate that in the case of future climate warming, with the growing seasons experiencing overall dryer and warmer environments and changes in vegetation communities, peatland NEE, ER, and GPP will increase and lead to the increase in ecosystem carbon accumulation.
\end{abstract}

Keywords: climate change; future climate scenario; peatland; CoupModel; carbon exchange

\section{Introduction}

According to the IPCC 'Special Report on Global Warming of $1.5{ }^{\circ} \mathrm{C}^{\prime}$, human-induced global warming has reached $0.87^{\circ} \mathrm{C}$ since the Industrial Revolution, and it is estimated to reach $1.5^{\circ} \mathrm{C}$ in the period 2030-2052 [1]. The global average temperature increased by $0.9^{\circ} \mathrm{C}$ during $2011-2015$ compared with that in 1750, and the average temperature increased by $0.2^{\circ} \mathrm{C}$ during 2015-2019 compared with that during 2011-2015 [2]. The rise in surface temperature induced by global warming is the most prominent in northern high latitudes [3]. Temperatures in northern latitudes are currently increasing at a rate of $0.6{ }^{\circ} \mathrm{C} / 10 \mathrm{yr}$, which is two times higher than the global average [4]. In particular, Northeast China exhibits the largest warming trend, with an increase rate of $0.36^{\circ} \mathrm{C} / 10 \mathrm{yr}$ [5].

Climate change is usually regarded as the most important driver of global soil carbon (C) stocks [6,7]. One of the most prominent aspects of climate change is global warming, which is mainly driven by the increase in greenhouse gas (GHG) concentrations in the atmosphere [8,9]. To maintain global warming below $2{ }^{\circ} \mathrm{C}, \mathrm{GHG}$ emissions have to be drastically reduced. Despite covering only $3 \%$ of the global land area, northern peatlands have accumulated large $C$ stocks [10]. According to statistics, one-third (455 PgC) of the global soil $\mathrm{C}$ is stored in northern peatlands, which play a critical role in $\mathrm{C}$ cycles on the global scale [11]. The balance between soil $C$ storage and loss will drive powerful carbon-climate feedback over the coming century. The representation of soil $\mathrm{C}$ cycling (both conceptually and numerically) has critical implications on the prediction of the response of peatlands to environmental change and anthropogenic forcing. For example, 
the response of peatlands to warming represents a critical source of uncertainty in efforts toward projecting carbon-climate feedbacks over the upcoming century [12].

Permafrost refers to ground that remains frozen for two or more consecutive years and underlies many Arctic and boreal ecosystems. In the current terrestrial ecosystem, permafrost represents the largest soil carbon pool at 1330-1580 Pg [13-15], which is significantly higher than the $\mathrm{C}$ content in vegetation $(650 \mathrm{Pg})$ and almost twice that in the atmosphere $(730 \mathrm{Pg})[16,17]$. Moreover, soil C storage in permafrost regions accounts for more than $50 \%$ of the global soil carbon [18]. However, permafrost in high latitudes and high altitudes is highly sensitive to climate change, and the growth rate of temperature in these regions in the past 30 years has been twice the global growth rate [19]. Permafrost temperature has increased by $0.29 \pm 0.12{ }^{\circ} \mathrm{C}$ between 2007 and 2016 on the global scale [20].

Permafrost and peatlands are interdependent in Northeast China. Under the unique cold, stagnant, and anaerobic environment of peatlands in permafrost regions [21], a large amount of $\mathrm{C}$ is stored in the soil. In peatlands, deeper water tables favor $\mathrm{CO}_{2}$ and $\mathrm{N}_{2} \mathrm{O}$ emissions and shallower water tables favor $\mathrm{CH}_{4}$ emissions [22,23]. As a result, these regions are more vulnerable to climate change and likely to release more GHGs in response to climate warming. Specifically, clarifying the carbon exchange process and emission characteristics of the peatland in the Great Hing'an Mountains in northern China is of great significance for reducing GHG emissions and controlling climate warming [24].

Vegetation plays a crucial role in carbon cycling and the thermal state of permafrost $[25,26]$. Climate warming generally leads to changes in vegetation composition and structure [27,28]. In recent decades, most boreal peatlands across the world have experienced substantial changes in vegetation composition and structure as a consequence of climate warming $[27,28]$. Field observations have consistently indicated that the expansion of shrubs and forbs has been changing pan-Arctic vegetation landscapes $[29,30]$. Specifically, the relative abundance of woody plants (i.e., trees and deciduous shrubs) has increased, and the cover of Sphagnum mosses and herbaceous plants has decreased and even disappeared [31,32]. The potential for ecosystems to store $C$ on an annual basis depends on the equilibrium between gross primary production (GPP) and the $C$ released from ecosystem respiration (ER), including plant and microbial respiration. Warmer temperatures can increase ER [33-35], which is driven by increases in both plant and microbial respiration $[33,36,37]$. Warming promotes woody-shrub expansion, which will increase plant productivity and litter input to soil [38-40]. The enhancement of plant productivity increases $C$ storage by plants, and thus could compensate for some of the $C$ loss from increased ER due to warmer temperatures [41,42]. However, long-term field observations of experimental permafrost warming have shown that ecosystem $C$ losses exceed $C$ gain after less than a decade [43,44].

Global climate is now warming rapidly because of vegetation changes in response to climatic change, and some terrestrial surfaces are expected to experience less water availability during the growing season in the future [45]. With the drying of the climate, the least drought-tolerant species are expected to disappear first. In the coming decades, long-term and continuous changes may have a significant impact on the distribution and function of vegetation [46]. The key issue is that seasonal changes in precipitation are more important to plant growth than annual changes. To control the rise in global mean temperatures, the reduction of $\mathrm{CO}_{2}$ emissions and storage of $\mathrm{CO}_{2}$ in land $\mathrm{C}$ sinks are indispensable. While the Great Hing'an Mountains ecosystem currently acts as a weak net carbon sink [47,48], with an average carbon accumulation rate of $42.65 \mathrm{~g} \mathrm{C} \mathrm{m}^{-2} \mathrm{yr}^{-1}$ over the past $2 \mathrm{ka}$ [48], climate change could increase the ER of peatland and weaken or reverse the sink function of this region in the future [48,49]. The consequences of climate change and vegetation change on the net ecosystem carbon balance remain uncertain [50-52]. As a result, the role of the permafrost region of the Great Hing'an Mountains as a carbon sink or source in the future is being actively debated [53-57].

To understand the regional consequences of climate and vegetation change and estimate the climate feedback of permafrost, future carbon emissions from peatlands can be quantified and predicted using CoupModel (a coupled heat and mass transfer model 
for soil-plant-atmosphere systems) [58]. CoupModel is a process-based biogeochemical model that focuses on heat and water transfer, and trace emissions from peatland ecosystems. This model combines biogeochemical processes with hydrological dynamics and has been constantly upgraded and improved. A large number of studies have shown that CoupModel is useful for simulating various types of emissions, such as heat transfer, water transfer, and GHGs [59-61].

With the continuous progress of global warming, a typical peat swamp located in the permafrost of the Great Hing'an Mountains in Northern China is being severely affected. In this study, carbon exchange in the peatland in the next 80 years was simulated and predicted. To this end, future scenario data of Coupled Model Intercomparison Project 5 (CMIP5) were analyzed using CoupModel and various preset vegetation succession schemes. The change trend and significant difference under different vegetation succession schemes were analyzed reasonably, and the influencing factors of carbon exchange in the future were clarified. This study could provide a reference in evaluating the changing trend and magnitude of the carbon exchange for the peatlands in the Great Hing'an Mountains.

\section{Materials and Methods}

\subsection{Study Area}

The study area is located in the Great Hing'an Mountains in Heilongjiang Province $\left(52^{\circ} 56^{\prime} 32.400^{\prime \prime} \mathrm{N}, 122^{\circ} 51^{\prime} 23.203^{\prime \prime} \mathrm{E}, 473 \mathrm{~m}\right.$ a.s.l.), which is a major permafrost area in China (Figure 1). The ecosystem of the Great Hing'an Mountains plays an important role in the stability of Asia's climate system, biodiversity, and regional carbon balance, making it indispensable to global biosphere integrity and the sustainable development of surrounding areas. The main soil type in the study area is humus swamp peat soil, with rich organic matter content. The peatland has continuously been acting as a sink for atmospheric $\mathrm{CO}_{2}$. The water table ranges between 10 and $32 \mathrm{~cm}$ below the soil surface in the growing season. The maximum thawing depth approximates $68 \mathrm{~cm}$ [62], and the depth greater than $70 \mathrm{~cm}$ is generally permafrost layer.

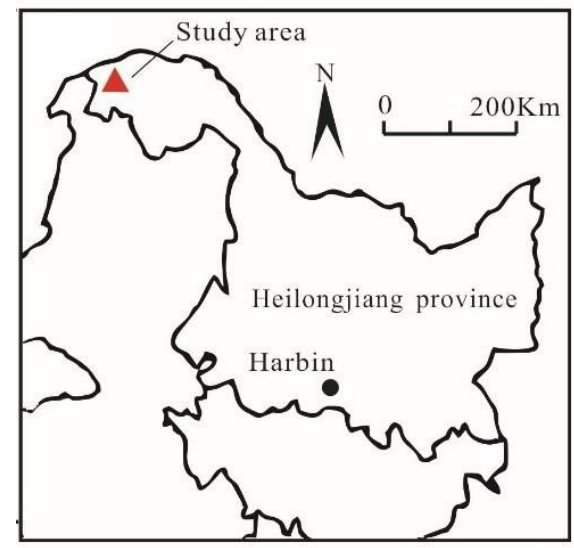

Figure 1. The study area in Heilongjiang Province.

\subsection{Vegetation and Meteorological Data}

The vegetation in the study area mainly includes deciduous shrubs, evergreen shrubs, sedges, and moss [63]. Seedlings of trees such as Larix gmelinii, Betula platyphylla, and Alnus sibirica, have widely expanded into the peatland [32]. In the simulation process, the vegetation layer is divided into two layers; the first layer is the herbaceous layer (average height $<15 \mathrm{~cm}$ ) and the second layer is the shrub layer (average height $>15 \mathrm{~cm}$ ). The area is located in the continental monsoon climate zone of the cold temperate zone, with an annual average temperature above $-4.00^{\circ} \mathrm{C}$, and precipitation is frequent in the warmest period (July and August) of the year, sustaining plant growth. Accordingly, we defined the growing season for the site as May to September. The warmest month is July $\left(18.75^{\circ} \mathrm{C}\right)$ and 
the coldest month is January $\left(-29.60^{\circ} \mathrm{C}\right)$. The annual precipitation and air temperature over the past 30 years (1981-2010) were $452.01 \mathrm{~mm}$ and $-3.90^{\circ} \mathrm{C}$, respectively.

\subsection{CoupModel}

CoupModel is a process-based model that describes the biogeochemical processes of carbon and nitrogen in various ecosystems [64]. The current version can be downloaded from the CoupModel home page [65]. A detailed description can be found in Jansson and Karlberg [66]. In the model, biological and physical processes that describe vegetation dynamics, snow dynamics, soil heat and water exchange, and soil bio-geochemistry are represented as individual modules [67]. The model can be used to project future conditions under given input scenarios. CoupModel inputs include meteorological data (such as radiation, precipitation, daily average temperature, and relative humidity), vegetation type, soil characteristics, and vegetation and initial soil element parameters, among others. During the simulation period, meteorological data series are in the form of daily averages. The model assumes constant physical properties of soil and vegetation type throughout the simulation period. The performance of CoupModel has been evaluated and reported to be reliable for $\mathrm{C}$ cycling simulation in previous studies. For example, based on eddycovariance (EC) measurements, CoupModel had been used to assess the annual $\mathrm{CO}_{2}$ budget for an Arctic ecosystem over a 5 year period [67].

\subsection{Model-Driven Data Construction}

\subsubsection{Data Source}

In this study, net ecosystem exchange (NEE) and ER fluxes in 2016 and 2019 were obtained using the static chamber/gas chromatography techniques and the detailed operation processes were consistent with Miao et al. 2012 [68]. The measurement frequency is one or two times per week (except for bad weather or fire prevention periods), and the average value was obtained from four repetitions of each measurement. In addition, air temperature and relative humidity, soil temperature, soil water content, wind speed, net radiation, and thawing depth in 2016 and 2019 were measured using the HMP45C temperature and relative humidity probe (Vaisala Inc, Helsinki, Finland), 107-l temperature probe (Campbell Scientific, NE, USA), CS616-l water content reflectometer (Campbell scientific, NE, USA), W200p wind vane (Vector Inc, Kuopio, Finland), CNR-1 net radiometer (Kipp and Zonen, NY, USA), and manual measurement, respectively. The thaw depth was measured manually once or twice a week during the observation period (except for bad weather and fire prevention period). Along the diagonal directions of the peatland, we measured the depth of the active layer by inserting a steel rod into the soil until maximum resistance, and then recorded the distance from the bottom of the probe to the surface layer. We chose 10 sites in each diagonal line and then calculated the averages. Current climate data and prediction data from five global climate models (GCMs) were selected to assess the sensitivity of peatland responses to climate change. In this study, the current climate data were obtained from the China National Meteorological Center (1959-2018, http:/ / data.cma.gov.cn, accessed on 10 December 2021). The future meteorological data (2006-2100) using five GCMs (GFDL-ESM2M, HadGEM2-ES, IPSL-CM5A-LR, MIROC-ESM-CHEM, NorESM1-M) under different future emission scenarios (Table 1) were obtained from CMIP5 (https:/ / cera-www.dkrz.de/WDCC/ui/cerasearch/, accessed on 10 December 2021). Previous studies have tested the performance of CMIP5 GCMs in northeastern China and reported that it could effectively represent the warming trend and interannual variation of precipitation in the study area $[69,70]$. In this study, the spatial resolutions of the input data and results were $0.5^{\circ} \times 0.5^{\circ}$. 
Table 1. Details of the 5 CMIP5 climate models.

\begin{tabular}{cccc}
\hline Model Name & Institution & Country & Spatial Resolution \\
\hline GFDL-ESM2M & NOAA & USA & $0.5^{\circ} \times 0.5^{\circ}$ \\
\hline HadGEM2-ES & MOHC & UK & $0.5^{\circ} \times 0.5^{\circ}$ \\
\hline IPSL-CM5A-LR & IPSL & France & $0.5^{\circ} \times 0.5^{\circ}$ \\
\hline MIROC-ESM-CHEM & MIROC & Japan & $0.5^{\circ} \times 0.5^{\circ}$ \\
\hline NorESM1-M & NCC & Norway & $0.5^{\circ} \times 0.5^{\circ}$ \\
\hline
\end{tabular}

\subsubsection{Future Climate-Driven Data}

The daily meteorological data from 2020 to 2100 (including temperature, precipitation, wind speed, net radiation, relative humidity, and snow) were selected to drive the CoupModel v6 simulation of the carbon cycles under climate change in the peatland. In addition, the model requires input describing the geographical coordinates, vegetation type, and soil physical and chemical parameters (texture, bulk density, and soil depth, as well as initial soil $\mathrm{C}$ content). Most of these input parameters were obtained through experimental measurements. The simulation results of the model were compared with the experimental data of the sites to verify the applicability of CoupModel to the study area.

\subsubsection{Representative Concentration Pathway (RCP) Emission Scenarios}

IPCC presented four future emission scenarios (RCP2.6, RCP4.5, RCP6.0, and RCP8.5) in 2014, which were combined with the changes in $\mathrm{CO}_{2}$ concentration. To ensure comparability of the results, RCP2.6 (mitigation scenario), RCP6.0 (stabilization scenario), and RCP8.5 (business-as-usual scenario) were selected in this study. Different emission scenarios were used to compare the radiative forcing reaching the Earth's surface and the atmospheric $\mathrm{CO}_{2}$ concentration by the year 2100 [71]. RCP emission scenarios can not only estimate the concentration of GHGs until the end of the 21st century or over longer time scales, but also convert dates into radiative forcing $\left(\mathrm{W} \mathrm{m}^{-2}\right)$. The basic information about the three scenarios is listed in Table 2.

Table 2. Radiation forcing reaching the Earth's surface and equivalent $\mathrm{CO}_{2}$ concentrations by 2100 under the three different emission scenarios.

\begin{tabular}{|c|c|c|c|}
\hline $\begin{array}{c}\mathbf{R C P} \\
\text { Scenarios }\end{array}$ & Emission Pattern & $\begin{array}{l}\text { Radiative Forcing } \\
\left(\mathrm{W} \mathrm{m}^{-2}\right) \text { until } 2100\end{array}$ & $\begin{array}{c}\mathrm{CO}_{2} \text { Concentration } \\
(\mathrm{ppm})\end{array}$ \\
\hline RCP2.6 & Mitigation scenario & $\begin{array}{l}\text { Reaches a peak of } 3.0 \mathrm{~W} \mathrm{~m}^{-2} \\
\text { before } 2100 \text { and then drops to } \\
2.6 \mathrm{~W} \mathrm{~m}^{-2}\end{array}$ & $\begin{array}{l}\text { Reaches a peak of } 490 \\
\text { ppm before } 2100 \text { and } \\
\text { then drops }\end{array}$ \\
\hline RCP6.0 & $\begin{array}{l}\text { Stabilization } \\
\text { scenario }\end{array}$ & $\begin{array}{l}\text { Stabilizes after reaching } \\
\quad 6.0 \mathrm{~W} \mathrm{~m}^{-2}\end{array}$ & $\begin{array}{l}\text { Reaches a peak of } 850 \\
\text { ppm before } 2100 \text { and } \\
\text { then drops }\end{array}$ \\
\hline RCP8.5 & $\begin{array}{l}\text { Business-as-usual } \\
\text { scenario }\end{array}$ & Reaches more than $8.5 \mathrm{~W} \mathrm{~m}^{-2}$ & $\begin{array}{l}\text { Reaches a peak of } 1370 \\
\text { ppm before } 2100 \text { and } \\
\text { then drops }\end{array}$ \\
\hline
\end{tabular}

\subsubsection{Model Performance Tests}

Based on the experimental results of the detailed survey data, the simulation results were compared with the measured data. The coefficient of determination $\left(R^{2}\right)$ and NashSutcliffe efficiency coefficient (NSE) were used to evaluate the goodness of fit between the simulation results and the measurement results. The mathematical expressions are as follows: 


$$
\begin{gathered}
R^{2}=1-\frac{\sum_{i=1}^{n}\left(S_{i}-M_{i}\right)^{2}}{\sum_{i=1}^{n}\left(\bar{S}-M_{i}\right)^{2}} \\
N S E=1-\frac{\sum_{i=1}^{n}\left(M_{i}-S_{i}\right)^{2}}{\sum_{i=1}^{n}\left(M_{i}-\bar{S}\right)^{2}}
\end{gathered}
$$

where $M_{i}$ is observed value, $S_{i}$ is simulated value, and $\bar{S}$ is average observed value.

\subsection{Methods}

To reflect the actual conditions as accurately as possible, we presented an estimate of climate warming for $\mathrm{C}$ losses of the peatland ecosystem under baseline (2020) and future climatic conditions (2100), and selected three representative time periods (2020-2030, 20502060, and 2090-2100), which represented the pre-century, mid-century, and late-century. In the process of simulation, we considered the change in vegetation type associated with long-term changes. Considering that terrestrial ecosystem models had quite different results on vegetation changes in both historical simulations and future predictions [72], we set a relatively moderate change on peatland vegetation by assuming a gradual increase in shrubs until the end of this century and an unchanged peatland vegetation patten as the current state. Accordingly, we ran CoupModel using two vegetation evolution schemes. For Scheme I, the proportion of herbaceous and shrub vegetation was assumed to remain close to the current vegetation situation and to remain stable until 2100. For Scheme II, herbaceous vegetation was assumed to be replaced by shrubs year by year, and the final vegetation type comprises only shrubs by 2100 . For the above two schemes, NEE, ER, and GPP were simulated. In the subsequent expressions, Scheme I and Scheme II were used to represent different trends on the succession schemes of peatland vegetations. Some of the parameters used in this study are shown in Table 3.

Table 3. The part of application parameters in the model.

\begin{tabular}{cccc}
\hline Parameters & Value & Default & Unit \\
\hline TemQ10 & 3 & 2 & Vol $\%$ \\
\hline Theta Lower Range & 2.5 & 13 & $/$ day \\
\hline $\mathrm{CH}_{4}$ Aerobic Ox Rate & 0.2 & 0.1 & $\mathrm{~m}$ \\
\hline Reference Height & 1.8 & 2 & ${ }^{\circ} \mathrm{C}$ \\
\hline Temp Air Mean & -2.1 & 10 & $\%$ \\
\hline Albedo Leaf & 15 & 25 & - \\
\hline RespTemQ10 & 3 & 2 & ${ }^{\circ} \mathrm{C}$ \\
\hline RespTemQ10Bas & 15 & 20 & $\%$ \\
\hline Albedo Dry & 10 & 30 & $\%$ \\
\hline Albedo Wet & 9 & 15 & - \\
\hline Latitude & 42.9 & 58.5 & \\
\hline
\end{tabular}

\section{Results}

\subsection{Comparison of Meteorological Observations and Meteorological Predictions}

The average temperature in the Great Hing' an Mountains was $-4.17^{\circ} \mathrm{C}$ from 1959 to 2018 and the average warming rate reached $0.25^{\circ} \mathrm{C} / 10 \mathrm{a}$; in 2015, the highest and lowest temperatures were $-2.51^{\circ} \mathrm{C}$ and $-6.27^{\circ} \mathrm{C}$, respectively (Figure 2). The annual average temperature was the lowest $\left(-2.68^{\circ} \mathrm{C}\right)$ under RCP2.6, followed by RCP6.0 $\left(-2.04{ }^{\circ} \mathrm{C}\right)$, and it was the highest $\left(-0.19^{\circ} \mathrm{C}\right)$ under RCP8.5. Under the three scenarios, temperature 
increased at rates of $0.26^{\circ} \mathrm{C} / 10 \mathrm{a}, 0.29^{\circ} \mathrm{C} / 10 \mathrm{a}$, and $0.67^{\circ} \mathrm{C} / 10 \mathrm{a}$, respectively (Figure 2), which are all higher than that during the past 60 years. The average temperature of the growing season was $10.61{ }^{\circ} \mathrm{C}$ in the past 60 years (Figure 2). The average temperature in the growing season was similar to the annual average temperature, with values of $11.60^{\circ} \mathrm{C}$, $12.31^{\circ} \mathrm{C}$, and $13.82{ }^{\circ} \mathrm{C}$ under RCP2.6, RCP6.0, and RCP8.5, respectively, which are higher than that in the past 60 years $\left(10.61^{\circ} \mathrm{C}\right)$ (Figures $\left.3-5\right)$.

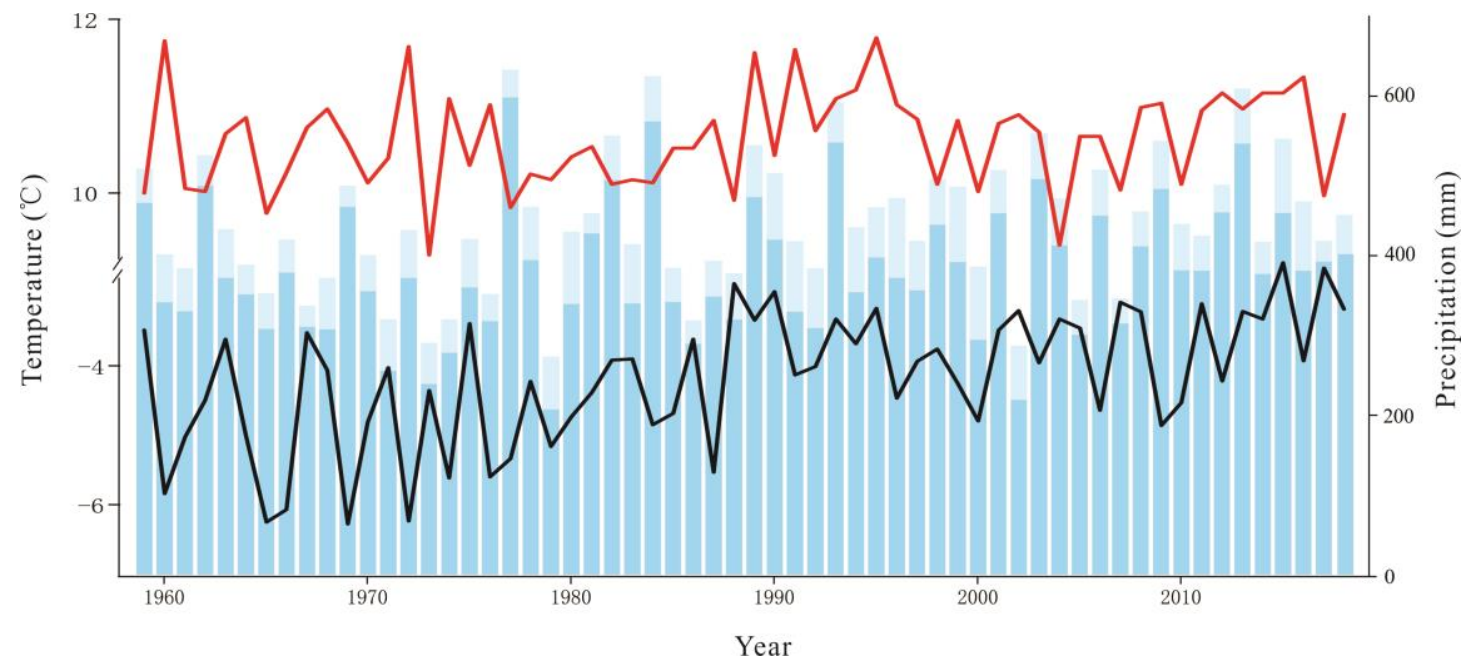

Figure 2. Interannual variations in air temperature (black solid line), interannual variations in growing season temperature (red solid line), the total annual precipitation (sum of column heights of blue and light blue), the growing season precipitation (the column height of light blue).
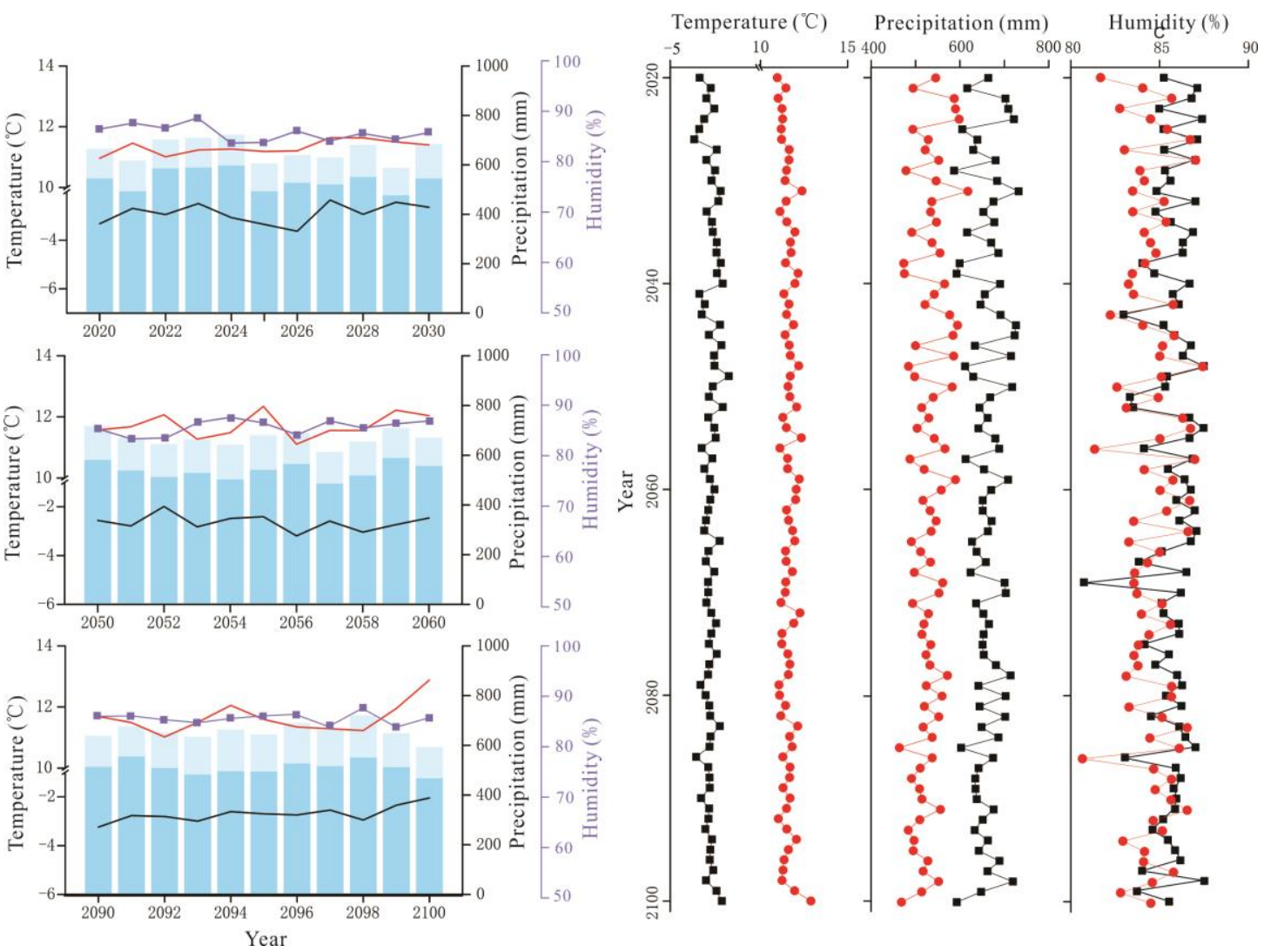

Figure 3. RCP2.6 scenario forecast meteorological data (2020-2100). On the left, interannual variations in air temperature (black solid line), interannual variations in growing season temperature (red solid 
line), interannual variations in relative humidity (blue purple square), the total annual precipitation (sum of column heights of blue and light blue) and the growing season precipitation (column height of light blue). On the right, interannual variations in annual air temperature, precipitation, and relative humidity (black solid square); interannual variations in growing season air temperature, precipitation, and relative humidity (red solid circle).
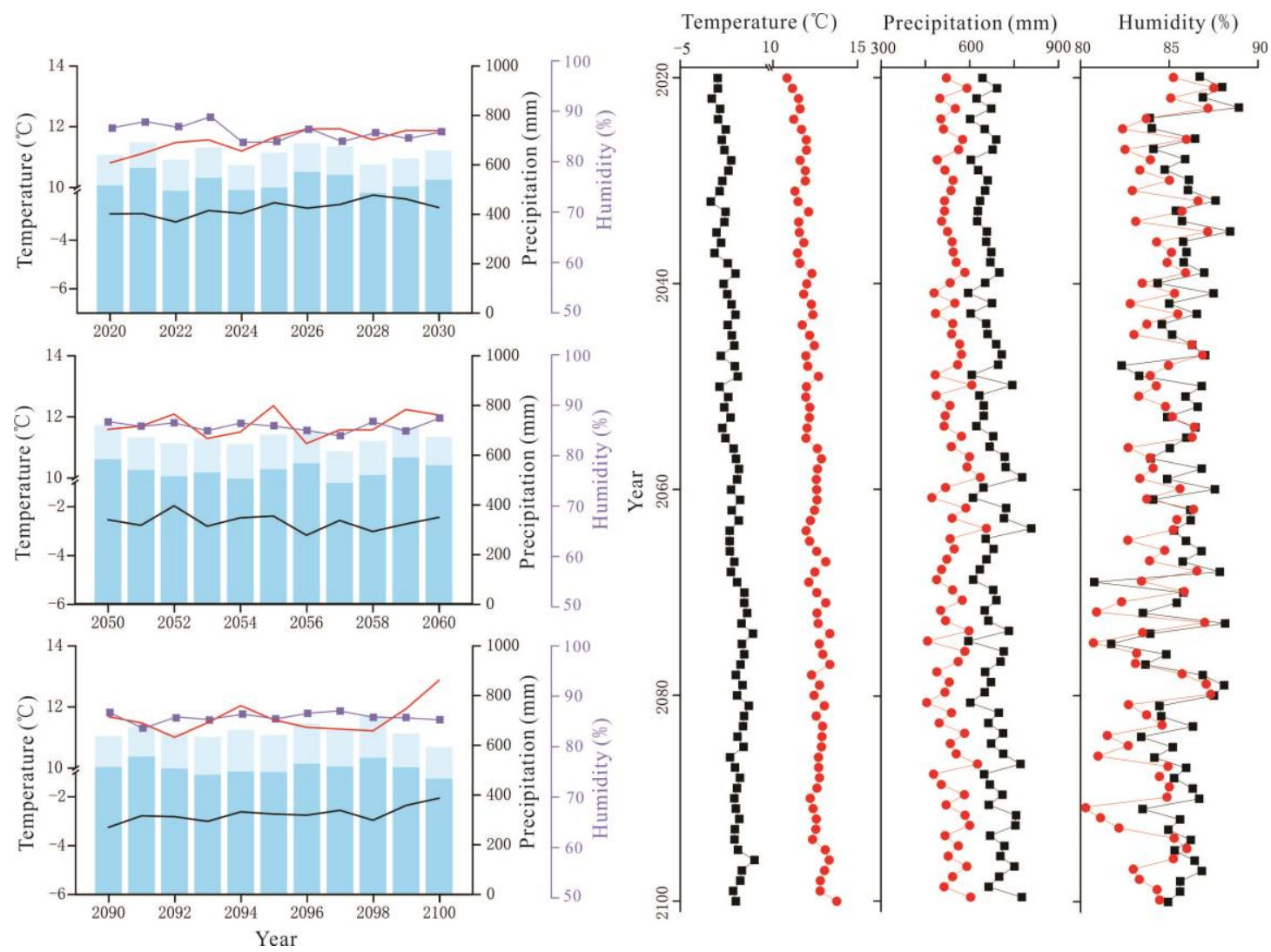

Figure 4. RCP6.0 scenario forecast meteorological data (2020-2100). The legend illustrates the same as Figure 3.

Precipitation initially decreased and then increased, and the average annual precipitation was $438.72 \mathrm{~mm}$ (Figure 2). The average annual precipitation in the growing season was $382.41 \mathrm{~mm}$ from 1959 to 2018 (Figure 2). The average annual precipitation under RCP2.6, RCP6.0, and RCP8.5 was $660.90 \mathrm{~mm}, 674.82 \mathrm{~mm}$, and $719.89 \mathrm{~mm}$, respectively, which values are higher than the average precipitation of the past 60 years (Figures $3-5$ ). The average annual precipitation in the growing season under RCP2.6, RCP6.0, and RCP8.5 was $529.98 \mathrm{~mm}, 539.86 \mathrm{~mm}$, and $572.05 \mathrm{~mm}$, respectively, which values are higher than that in the past 60 years. Under the three scenarios, the annual average relative humidity showed a decreasing trend, with values of $85.67 \%, 85.58 \%$, and $85.10 \%$ under RCP2.6, RCP6.0 and RCP8.5, respectively (Figures 3-5). In general, precipitation increased at the annual scale, but no distinct intensity changes were observed between wet and dry seasons, potentially because of the warming-driven increase in evapotranspiration. 

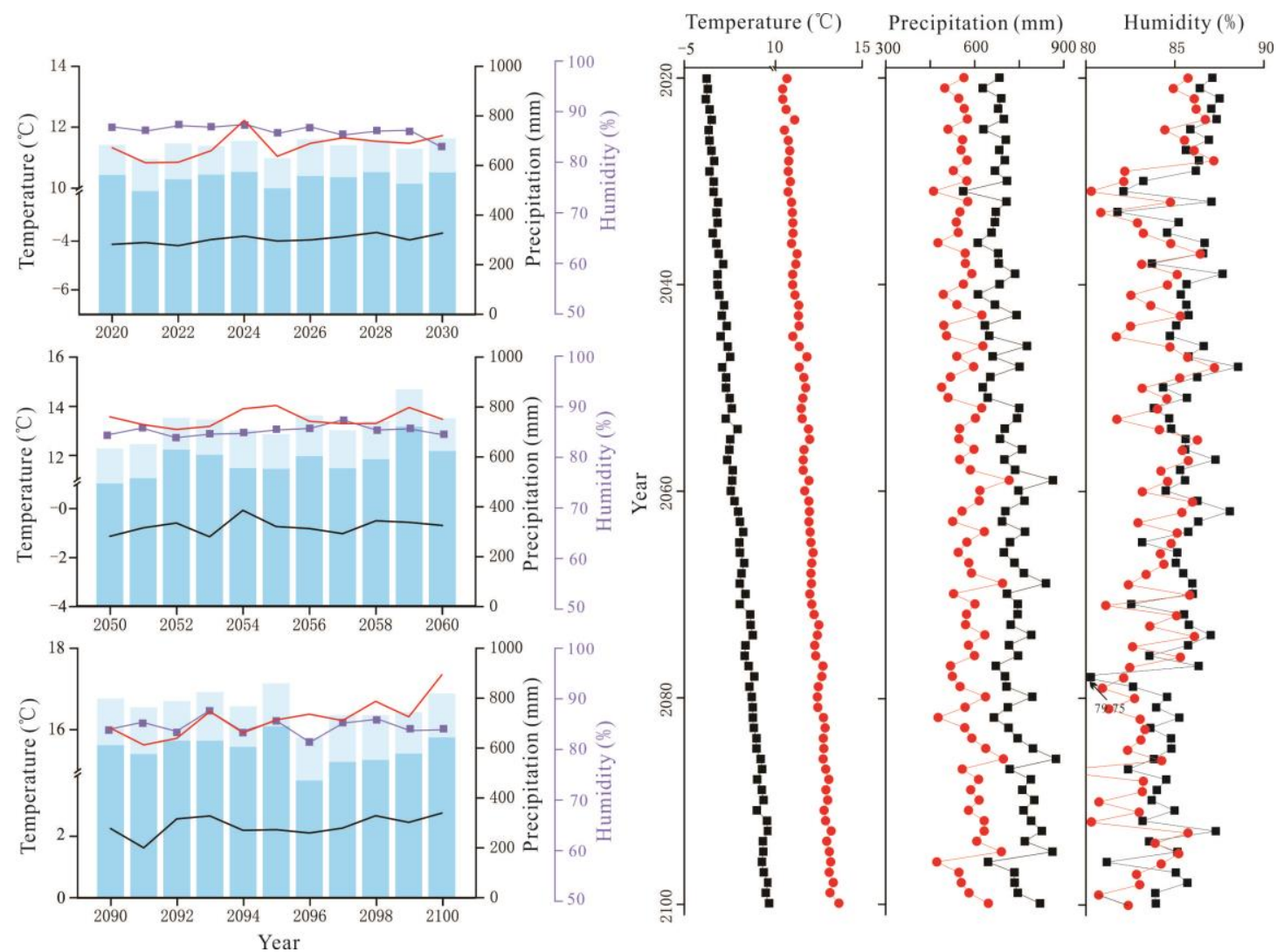

Figure 5. RCP8.5 scenario forecast meteorological data (2020-2100). The legend illustrates the same as Figure 3.

\subsection{Calibration and Validation of CoupModel}

Firstly, the model was calibrated based on the measured NEE, ER, soil temperatures and soil water content at depths from $-5 \mathrm{~cm}$ to $-40 \mathrm{~cm}$, and freezing-thawing depth. Subsequently, we validated the simulation results against the experimental site data (soil temperature, water content, NEE, ER, and thawing depth during the growing season) to verify the applicability of the model to the study area. We compared the output from model simulations corresponding to the present day against the observations to validate the model performance. Finally, we used observation data covering the growing seasons of 2016 and 2019 to calibrate plant parameters and soil parameters in the model. Initial soil temperature, initial water content, growing degree days, carbon/nitrogen ratios, $\mathrm{pH}, \mathrm{SOC}$, and bulk density are the most sensitive parameters. In addition, we also determined some parameters applicable to the model in the region, as shown in Table 3.

In the verification of the applicability of CoupModel to the study area, we carried selected representative dates from different years. Figure 6 shows the comparison between simulated and measured soil temperature values at different depths. The simulated soil temperature and soil water contents were close to the measured value in terms of size and variation trend. 


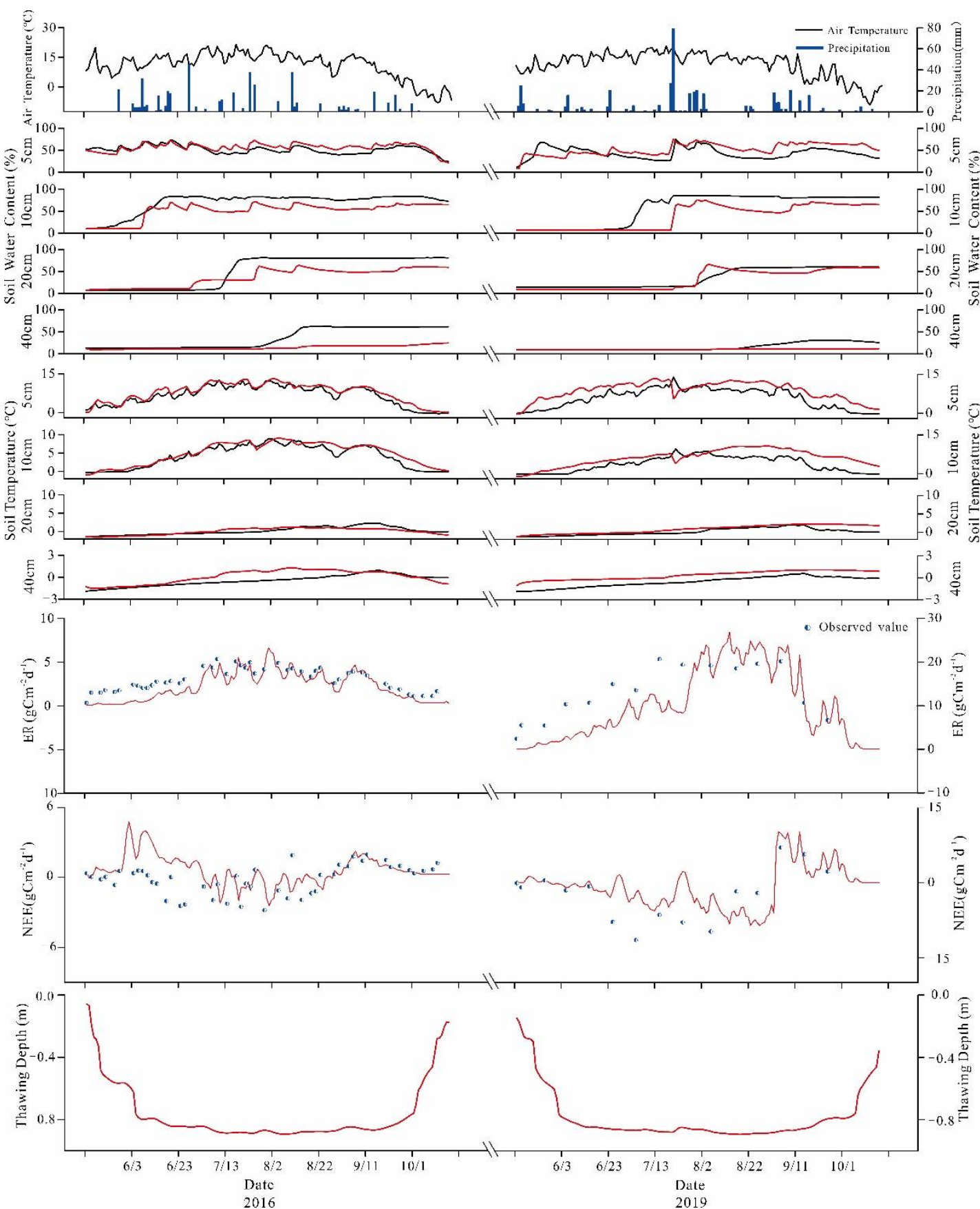

Figure 6. Soil temperature, water content, NEE, ER, and thawing depth in growing seasons of 2016 and 2019; the red solid lines represent the simulation results of the model, the black solid lines and blue and white circles represent the observed results.

\subsection{Changes in Peatland NEE, ER, and GPP under Three Future Climate Change Scenarios}

Changes in NEE, ER, and GPP during various time periods were analyzed under various future climate change scenarios. With Scheme I, the simulated changes in NEE followed the order of RCP2.6 $\left(-3.33 \mathrm{kgcm}^{-2}\right)<$ RCP8.5 $\left(-3.40 \mathrm{kgcm}^{-2}\right)<$ RCP6.0 $\left(-3.41 \mathrm{kgcm}^{-2}\right)$, and the changes under RCP2.6 and RCP6.0 exhibited an increasing trend with time (Figure 7). The change trend of NEE with Scheme I under RCP8.5 was the most prominent by the end of the century. The predicted ER and GPP changes in various time periods under different scenarios from 2010 to 2100 are similar. Positive effects were stronger under RCP6.0 and RCP8.5 than under RCP2.6. In particular, the positive effect was significantly stronger under RCP8.5. Among them, the change trends were similar 
between ER and GPP, which followed the orders of RCP2.6 $\left(39.00 \mathrm{kgcm}^{-2}\right)<$ RCP6.0 (41.48 $\left.\mathrm{kgcm}^{-2}\right)<$ RCP8.5 $\left(47.42 \mathrm{kgcm}^{-2}\right)$ and RCP2.6 $\left(42.34 \mathrm{kgcm}^{-2}\right)<$ RCP6.0 $\left(44.90 \mathrm{kgcm}^{-2}\right)<$ RCP8.5 (50.88 $\left.\mathrm{kgcm}^{-2}\right)$, respectively.
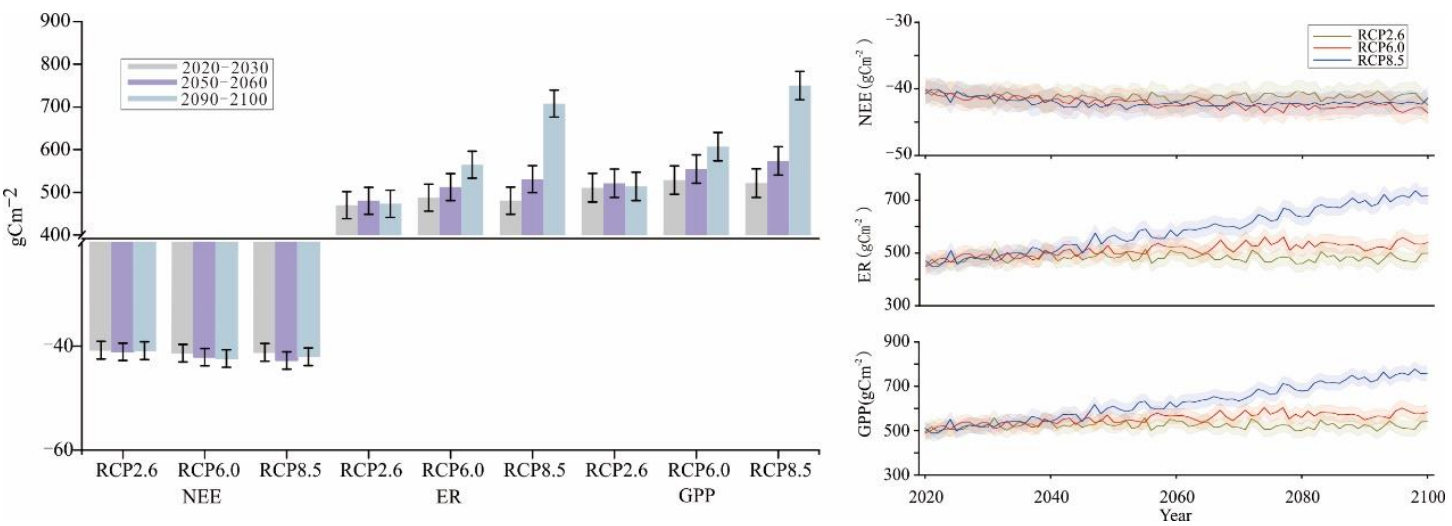

Figure 7. Simulation results of NEE, ER, and GPP from 2021 to 2100 in Scheme I.

With Scheme II, the simulated changes in NEE were slightly different (Figure 8), following the order of RCP2.6 $\left(-3.59 \mathrm{kgcm}^{-2}\right)<\mathrm{RCP} 6.0\left(-3.66 \mathrm{kgcm}^{-2}\right)<\operatorname{RCP} 8.5(-3.67$ $\mathrm{kgcm}^{-2}$ ). The change trend of NEE with Scheme II under RCP8.5 was similar to that with Scheme I by the end of the 21st century. The predicted changes in ER and GPP during various time periods under different scenarios from 2010 to 2100 were also similar to those with Scheme I. The positive effects were stronger under RCP6.0 and RCP8.5 than under RCP2.6. In particular, the effect was significantly stronger under RCP8.5. The change trends were similar between ER and GPP, which followed the orders of RCP2.6 $\left(42.14 \mathrm{kgcm}^{-2}\right)$ $<$ RCP6.0 $\left(43.90 \mathrm{kgcm}^{-2}\right)<$ RCP8.5 $\left(50.29 \mathrm{kgcm}^{-2}\right)$ and RCP2.6 $\left(44.83 \mathrm{kgcm}^{-2}\right)<$ RCP6.0 $\left(47.66 \mathrm{kgcm}^{-2}\right)<$ RCP8.5 $\left(53.96 \mathrm{kgcm}^{-2}\right)$, respectively.

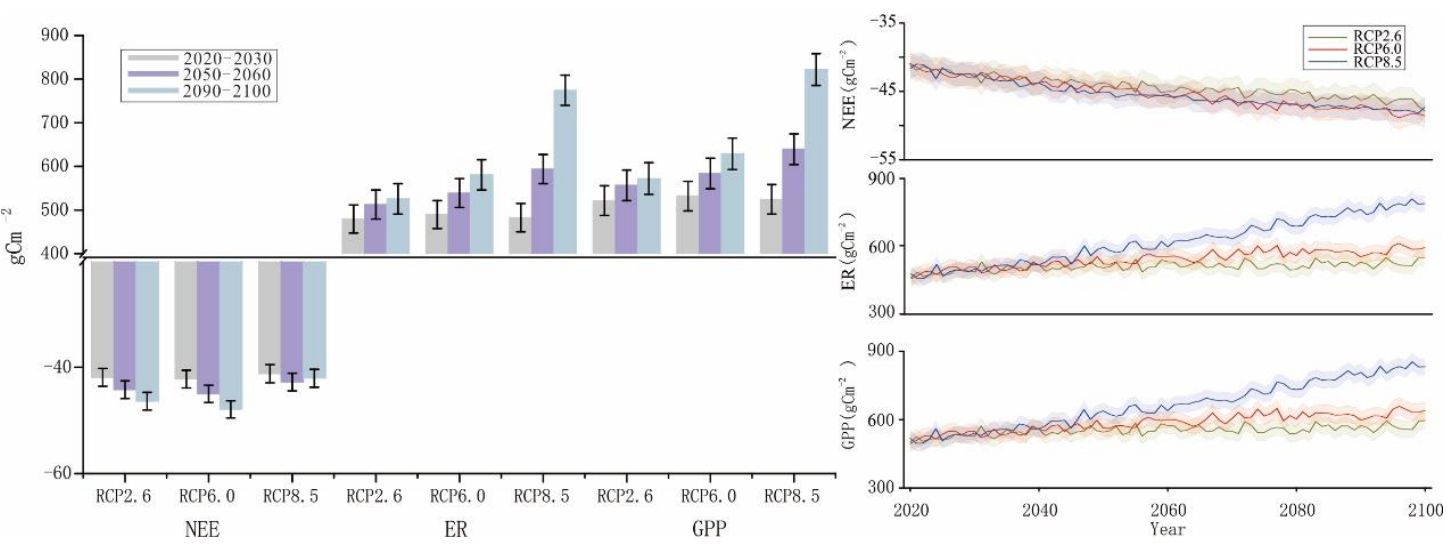

Figure 8. Simulation results of NEE, ER, and GPP from 2021 to 2100 in Scheme II.

\section{Discussion}

\subsection{Comparison of Simulation Results between Scheme I and Scheme II}

To explore the response trends of vegetation with the two schemes to future climate change, we analyzed the simulation results of NEE, GPP, and ER with the two vegetation schemes in different time periods, and compared the differences between them. On the one hand, at the same time scale, the simulation results of NEE, GPP, and ER with the two schemes will increase under different scenarios from RCP2.6 to RCP8.5. It could be concluded that relatively moderate climate change has an apparent positive effect on the peatland ecosystems. Extension of growing season [67] and more plant biomass could lead to higher autotrophic respiration [73]. Considering the impact of climate change 
and plant biomass, it is worth noting that ER and GPP will increase significantly under RCP6.0 and RCP8.5. Overall, the carbon sequestration capacity of the peatland ecosystem showed a weak increasing trend and remained stable by the end of the 21st century. On the other hand, when the climate change reaches a certain degree, it will form a negative correlation with the carbon sequestration capacity of the peatland ecosystem, which means the carbon sink capacity will be weakened. In particular, NEE shows a decreasing trend after 2053 under RCP8.5. The results show that the changes in NEE of the two vegetation schemes under the RCP8.5 in the peatland ecosystem will decrease by the end of the 21st century relative to the values during 2050-2060. This trend is different from the emission pattern under RCP2.6 and RCP6.0. Both the simulation results of the carbon dynamics of pan-Arctic peatlands show that the carbon sink capacity of the peatlands will be weakened from the middle of the 21st century under RCP8.5 [48]. Finally, the overall trends in the simulation results with the two vegetation schemes are similar, but the specific values show that Scheme II is greater than Scheme I. The main reason is that with Scheme II, the number of shrubs will increase annually, and the photosynthesis, respiration, and carbon sequestration capacities of shrubs are higher than those of herbaceous plants. This shows that the change in vegetation type will lead to the change in carbon budget. In addition, there were significant differences in NEE, ER, and GPP for the two schemes. Peatlands associated with graminoid-dominated vegetation experience greater carbon losses from decomposition and are more sensitive to temperature than shrub-dominated soils.

\subsection{Turning Point of NEE Trend}

The two schemes showed clear trend changes in 2053. Before 2053, the NEE exchange rate was large, but it became much gentler after 2053. The trend change of NEE in 2053 under RCP8.5 may be mainly attributable to temperature. Therefore, the temperature under RCP8.5 was divided into two periods of 2021-2053 and 2053-2100 with 2053 as the dividing point, and the average annual temperature was compared and the significance of the difference was analyzed. The results show that the average annual temperatures during 2021-2053 and 2053-2100 are $-1.88{ }^{\circ} \mathrm{C}$ and $0.99{ }^{\circ} \mathrm{C}$, respectively, and the temperature difference between the two periods is extremely significant $(p<0.01)$. We can conclude that in the context of future warming and drying, with the increase in shrub plants, the carbon sink capacity of the peatland ecosystem in the Great Hing'an Mountains will increase, but when the temperature reaches a certain threshold, the carbon sink capacity of the ecosystem will be weakened.

\subsection{Analysis of Environmental Factors Affecting NEE, ER, and GPP Changes}

Warming can have multiple effects on ER and primary productivity, two of the major vertical carbon fluxes [74]. Higher temperatures can extend the growing season, potentially enhancing vegetation GPP [75]. The correlation analysis method was used to determine the influence of environmental factors on the NEE, ER, and GPP of the peatland ecosystem in the permafrost region of the Great Hing'an Mountains. The results passed the significance test at the level of 0.1 (Tables S1-S6 in Supplementary Materials). For different scenarios, the influence of environmental factors on ER and GPP was slightly different with the two schemes. It is worth noting that with Scheme II under RCP2.6, NEE, ER, and GPP exchange rates were significantly positively correlated with temperature $(p<0.1)$. In addition, both ER and GPP in Scheme I under RCP2.6 and NEE and ER in Scheme II under RCP8.5 were significantly positively correlated with relative humidity $(p<0.1)$. Combined with the results of the environmental factors analysis, under climate change, temperature appears to be an important factor affecting ecosystem carbon exchange, with precipitation, radiation, and relative humidity also having certain influences (Figure 9). 


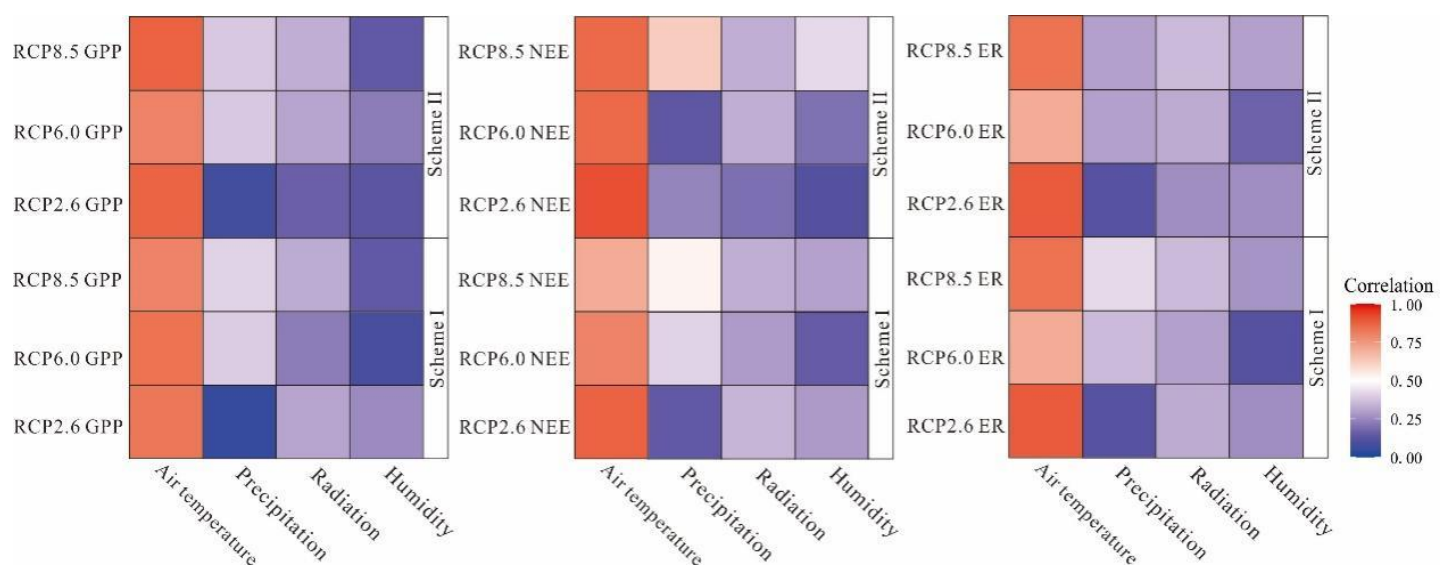

Figure 9. Correlation diagram between simulation results and meteorological elements.

\subsection{Uncertainty Analysis of Simulation Results}

Previous studies found that the annual carbon assimilations from swamp or peatland in the regions of Hing'an Mountains were mostly attributable to the uptakes during the growing seasons, particularly from June to August $[53,62,68]$. The net carbon assimilation by plants during the growing seasons was generally higher than the carbon emitted during the non-growing seasons [76]. Climate warming extends or alters the growing season [67], enhances the warmth of summer, and increases the carbon sink capacity of vegetation. However, it should be noted that it is still unknown whether the carbon released by the permafrost ecosystem and the carbon absorbed by summer plant growth can be completely offset. There may be more uncertainties in the process of the model prediction with the continuous change of climate in the future, as well as a series of problems such as the internal structure of the model and the uncertainty of key input parameters, which eventually affect the simulation results of carbon sources/sinks in ecosystems to some extent. For example, with climate change, the effect of fertilization driven by the increase in $\mathrm{CO}_{2}$ concentration is also likely to increase the peatland carbon sink through increases in primary productivity. Recent field experiments suggest that permafrost thawing might promote deeper rooting of some plant species $[77,78]$ that attempt to exploit plant-available nutrients at the permafrost thaw front $[79,80]$.

Soil has high spatial variability, slow change rate, and many processes affecting its decomposition rate. Therefore, variations in soil and its characteristics will lead to uncertainties because most $C$ is stored in soil. In addition, if the water content remains unchanged and the vegetation changes, increased woody vegetation will promote $\mathrm{C}$ accumulation [81]. Increases in shrubs and trees have also been shown to increase the pools of phenolic compounds and decrease the loss of peat carbon to the atmosphere [82]. The additional rhizosphere effect also deserves further attention. A previous study suggested that additional rhizodeposition with climate warming will promote carbon decomposition [83]. Higher temperatures and reduced rainfall have negative effects on productivity by increasing evapotranspiration and decreasing soil moisture [84-87].

The different definitions of vegetation types between the initial input data and CoupModel could also introduce uncertainties in the model simulation. Research relying only on individual model simulations still have inherent limitations. However, the strength of this feedback is highly uncertain; indeed, it is now one of the largest uncertainties in future climate predictions [88]. In addition, because changes in the active layer of frozen soil affect the measurements, our simulation results contain some inevitable errors. Nevertheless, our results are expected to complement early detection of changes in the role of the peatland as a source or sink. In future efforts, we will attempt to reduce these errors as much as possible. Our model projections also did not incorporate all changes expected under future climates, such as changes in permafrost distribution, delayed seasonal freeze-up, increased fire frequency, landscape-level hydrologic changes, mycorrhizal type, and mycorrhizal dis- 
tribution. Therefore, we hope that the above factors can be taken into account in subsequent applications.

\section{Conclusions}

In this study, CoupModel could be well applied to our study area, and the simulation results are also convincing. According to the climate change trend in the future, two vegetation succession schemes were set. Combined with CoupModel, the carbon exchange of the ecosystem was simulated using meteorological data for the next 80 years of the Great Hing'an Mountains. Moreover, the simulation results show that after 2053, under the high warming scenario, the carbon sink capacity of the Great Hing'an Mountains ecosystem may be reduced.

It should be noted that long-term changes in vegetation structure and composition may alter the response and control of soil carbon exchange in ecosystems to future climate change. Therefore, further studies are necessary to explore the effects of changes in vegetation types and their response to elevated temperatures. In this manner, responses and feedback in biogeochemical cycling to global warming in boreal peatlands can be more accurately predicted. Our results are reassuring, showing that the carbon sink of natural peatland may increase in the future. With the ongoing global change, the function of northern peatlands remains uncertain, especially those underlain by permafrost in the climate system. Our research could thus provide some scientific references in assessing the role of northern peatlands from the perspective of their carbon exchanges with the atmosphere.

Supplementary Materials: The following are available online at https:/ /www.mdpi.com/article/ 10.3390/atmos13010044/s1, Table S1: The correlation analysis between NEE simulation value and environmental factors in Scheme I, Table S2: The correlation analysis between NEE simulation value and environmental factors in Scheme II, Table S3: The correlation analysis between ER simulation value and environmental factors in Scheme I, Table S4: The correlation analysis between ER simulation value and environmental factors in Scheme II, Table S5: The correlation analysis between GPP simulation value and environmental factors in Scheme I, Table S6: The correlation analysis between GPP simulation value and environmental factors in Scheme II.

Author Contributions: Data curation, Z.W.; Writing—original draft, Y.L.; Writing—review \& editing, L.S. All authors have read and agreed to the published version of the manuscript.

Funding: This research received no external funding.

Institutional Review Board Statement: Not applicable.

Informed Consent Statement: Not applicable.

Data Availability Statement: Not applicable.

Acknowledgments: This work has been supported by the National Natural Science Foundation of China (41771102). We gratefully acknowledge the anonymous reviewers for their comments on earlier versions of this paper. We thank Mousong Wu, Wenxin Zhang, Hongxing He and Guojie Hu for their guidance on model running.

Conflicts of Interest: The authors declare no conflict of interest.

\section{References}

1. IPCC. Special Report on Global Warming of $1.5^{\circ} \mathrm{C}$; Cambridge University Press: London, UK, 2018.

2. Mingle, J. IPCC Special Report on the Ocean and Cryosphere in a Changing Climate; New York Review of Books: New York, NY, USA, 2020; pp. 49-51.

3. Overland, J.E.; Wang, M.Y.; Walsh, J.E.; Stroeve, J.C. Future Arctic climate changes: Adaptation and mitigation time scales. Earths Future 2014, 2, 68-74. [CrossRef]

4. IPCC. Climate Change 2013: The Physical Science Basis. Contribution of Working Group I to the Fifth Assessment Report of the Intergovernmental Panel on Climate Change; Cambridge University Press: Cambridge, UK; New York, NY, USA, 2013.

5. Piao, S.; Ciais, P.; Huang, Y. The impacts of climate change on waterresources and agriculture in China. Nature 2010, $2,467$. 
6. Jobbágy, E.G.; Jackson, R.B. The vertical distribution of soil organic carbon and its relation to climate and vegetation. Ecol. Appl. 2000, 10, 423-436. [CrossRef]

7. Wiesmeier, M.; Urbanski, L.; Hobley, E.; Lang, B.; Lützow, M.; Marin-Spiotta, E.; van Wesemael, B.; Rabot, E.; Ließ, M.; GarciaFranco, N.; et al. Soil organic carbon storage as a key function of soils-A review of drivers and indicators at various scales. Geoderma 2019, 333, 149-162. [CrossRef]

8. Kumar, A.; Kumar, M.; Pandey, R.; ZhiGuo, Y.; Cabral-Pinto, M. Forest soil nutrient stocks along altitudinal range of Uttarakhand Himalayas: An aid to Nature Based Climate Solutions. CATENA 2021, 207, 105667. [CrossRef]

9. Nilawar, A.P.; Waikar, M.L. Impacts of climate change on streamflow and sediment concentration under RCP 4.5 and 8.5: A case study in Purna river basin, India. Sci. Total Environ. 2019, 650, 2685-2696. [CrossRef] [PubMed]

10. Roulet, N.T.; Lafleur, P.M.; Richard, P.J.H.; Moore, T.R.; Humphreys, E.R.; Bubier, J. Contemporary carbon balance and late Holocene carbon accumulation in a northern peatland. Glob. Chang. Biol. 2007, 13, 397-411. [CrossRef]

11. Gorham, E. Northern Peatlands: Role in the Carbon Cycle and Probable Responses to Climatic Warming. Ecol. Appl. 1991, 1, 182-195. [CrossRef]

12. Bradford, M.A.; Wieder, W.R.; Bonan, G.B.; Fierer, N.; Raymond, P.A.; Crowther, T.W. Managing uncertainty in soil carbon feedbacks to climate change. Nat. Clim. Chang. 2016, 6, 751-758. [CrossRef]

13. Zimov, S.A.; Schuur, E.A.G.; Chapin, F.S. Permafrost and the global carbon budget. Science 2006, 312, 1612-1613. [CrossRef]

14. Hugelius, G.J.; Strauss, S.; Zubrzycki, J.W.; Harden, E.A.G.; Schuur, C.L.; Ping, L.; Schirrmeister, G.; Grosse, G.J.; Michaelson, C.; Koven, J.; et al. Estimated stocks of circumpolar permafrost carbon with quantified uncertainty ranges and identified data gaps. Biogeosciences 2014, 11, 6573-6593. [CrossRef]

15. Schuur, E.A.G.; McGuire, A.D.; Schädel, C.; Grosse, G.; Harden, J.W.; Hayes, D.J.; Hugelius, G.; Koven, C.D.; Kuhry, P.; Lawrence, D.M.; et al. Climate change and the permafrost carbon feedback. Nature 2015, 520, 171-179. [CrossRef]

16. Buchanan, P.J.; Matear, R.J.; Lenton, A.; Phipps, S.J.; Chase, Z.; Etheridge, D.M. The simulated climate of the Last Glacial Maximum and insights into the global marine carbon cycle. Clim. Past 2016, 12, 2271-2295. [CrossRef]

17. Lacerra, M.; Lund, D.; Yu, J.M.; Schmittner, A. Carbon storage in the mid-depth Atlantic during millennial-scale climate events. Paleoceanography 2017, 32, 780-795. [CrossRef]

18. Johnston, C.E.; Ewing, S.A.; Harden, J.W.; Varner, R.K.; Wickland, K.P.; Koch, J.C.; Fuller, C.C.; Manies, K.; Jorgenson, M.T. Effect of permafrost thaw on $\mathrm{CO}_{2}$ and $\mathrm{CH}_{4}$ exchange in a western Alaska peatland chronosequence. Environ. Res. Lett. 2014, 9, 0850048.

19. Pörtner, H.O.; Roberts, D.C.; Masson-Delmotte, V.; Zhai, P.; Tignor, M.; Poloczanska, E.; Mintenbeck, K.; Alegría, A.; Nicolai, M.; Weyer, N.M.; et al. IPCC Special Report on the Ocean and Cryosphere in a Changing Climate. 2019. Available online: https:/ / www.eea.europa.eu/data-and-maps/indicators/arctic-sea-ice-3/ipcc-4th-assessment-report-2007 (accessed on 10 December 2021).

20. Biskaborn, B.K.; Smith, S.L.; Noetzli, J.; Matthes, H.; Vieira, G.; Lantuit, H. Permafrost is warming at a global scale. Nat. Commun 2019, 10, 264. [CrossRef] [PubMed]

21. Baird, A.J.; Belyea, L.R.; Comas, X.; Reeve, A.S.; Slater, L.D. Understanding Carbon Cycling in Northern Peatlands: Recent Developments and Future Prospects; American Geophysical Union: Washington, DC, USA, 2009.

22. Couwenberg, J. Assessing greenhouse gas emissions from peatlands using vegetation as a proxy. Hydrobiologia 2011, 674, 67-89. [CrossRef]

23. Tiemeyer, B. High emissions of greenhouse gases from grasslands on peat and other organic soils. Glob. Chang. Biol. 2016, 22, 4134-4149. [CrossRef]

24. Zhang, L.; Gałka, M.; Kumar, A.; Liu, M.; Knorr, K.H.; Yu, Z.G. Plant succession and geochemical indices in immature peatlands in the Changbai Mountains, northeastern region of China: Implications for climate change and peatland development. Sci. Total Environ. 2021, 773, 143776. [CrossRef]

25. Shur, Y.L.; Jorgenson, M.T. Patterns of permafrost formation and degradation in relation to climate and ecosystems. Permafr. Periglac. Process 2007, 18, 7-19. [CrossRef]

26. Loranty, M.M.; Abbott, B.W.; Blok, D.; Douglas, T.A.; Epstein, H.E.; Forbes, B.C.; Jones, B.M.; Kholodov, A.L.; Kropp, H.; Malhotra, A. Reviews and syntheses: Changing ecosystem influences on soil thermal regimes in northern high-latitude permafrost regions. Biogeosciences 2018, 15, 5287-5313. [CrossRef]

27. Dieleman, C.M.; Branfireun, B.A.; McLaughlin, J.W.; Lindo, Z. Climate change drives a shift in peatland ecosystem plant community: Implications for ecosystem function and stability. Glob. Chang. Biol. 2015, 21, 388-395. [CrossRef]

28. Robroek, B.J.M.; Jassey, V.E.J.; Payne, R.J.; Marti, M.; Bragazza, L.; Bleeker, A.; Buttler, A.; Caporn, S.J.M.; Dise, N.B.; Kattge, J.; et al. Taxonomic and functional turnover are decoupled in European peat bogs. Nat. Commun. 2017, 8, 1161. [CrossRef]

29. Elmendorf, S.C.; Henry, G.H.R.; Hollister, R.D.; Bjork, R.G.; Boulanger-Lapointe, N.; Cooper, E.J.; Cornelissen, J.H.C.; Dorrepaal, E.; Elumeeva, T.G.; Gould, A.; et al. Plot-scale evidence of tundra vegetation change and links to recent summer warming. Nat. Clim. Chang. 2012, 2, 453-457. [CrossRef]

30. Myers-Smith, I.H.; Elmendorf, S.C.; Beck, P.S.A.; Wilmking, M.; Hallinger, M.; Blok, D.; Tape, K.D.; Rayback, S.A.; .Macias-Fauria, M.; Forbes, B.C.; et al. Climate sensitivity of shrub growth across the tundra biome. Nat. Clim. Chang. 2015, 5, 887-891. [CrossRef]

31. Buttler, A.; Robroek, B.J.M.; Laggoun-Defarge, F.; Jassey, V.E.J.; Pochelon, C.; Bernard, G.; Delarue, F.; Gogo, S.; Mariotte, P.; Mitchell, E.A.D.; et al. Experimental warming interacts with soil moisture to discriminate plant responses in an ombrotrophic peatland. J. Veg. Sci. 2015, 26, 964-974. [CrossRef] 
32. Chen, H.; Song, C.; Shi, F.; Zhang, X.; Mao, R. Effects of alder expansion on plant community composition and biomass in the peatland in the Da'xingan Mountain. Chin. J. Appl. Environ. Biol. 2017, 23, 778-784. (In Chinese)

33. Hobbie, S.E.; Chapin, F.S. Response of tundra plant biomass, aboveground production, nitrogen, and $\mathrm{CO}_{2}$ flux to experimental warming. Ecology 1998, 79, 1526-1544.

34. Natali, S.M.; Schuur, E.A.G.; Webb, E.E.; Pries, C.E.H.; Crummer., K.G. Permafrost degradation stimulates carbon loss from experimentally warmed tundra. Ecology 2014, 95, 602-608. [CrossRef]

35. Mauritz, M.; Bracho, R.; Celis, G.; Hutchings, J.; Natali, S.M.; Pegoraro, E.; Salmon, V.G.; Schädel, C.; Webb, E.E.; Schuur, E.A.G. Nonlinear $\mathrm{CO}_{2}$ flux response to 7 years of experimentally induced permafrost thaw. Glob. Chang. Biol. 2017, 23, 3646-3666. [CrossRef]

36. Pries, C.E.H.; Schuur, E.A.G.; Crummer, K.G. Thawing permafrost increases old soil and autotrophic respiration in tundra: Partitioning ecosystem respiration using delta ${ }^{13} \mathrm{C}$ and Delta ${ }^{14} \mathrm{C}$. Glob. Chang. Biol. 2013, 19, 649-661. [CrossRef]

37. Pries, C.E.H.; Schuur, E.A.G.; Natali, S.M.; Crummer, K.G. Old soil carbon losses increase with ecosystem respiration in experimentally thawed tundra. Nat. Clim. Chang. 2016, 6, 214-218. [CrossRef]

38. Chapin, F.S.; Shaver, G.R.; Giblin, A.E.; Nadelhoffer, K.J.; Laundre, J.A. Responses of Arctic tundra to experimental and observed changes in climate. Ecology 1995, 76, 694-711. [CrossRef]

39. Natali, S.M.; Schuur, E.A.G.; Rubin, R.L. Increased plant productivity in Alaskan tundra as a result of experimental warming of soil and permafrost. J. Ecol. 2012, 100, 488-498. [CrossRef]

40. Sistla, S.A.; Moore, J.C.; Simpson, R.T.; Gough, L.; Shaver, G.R.; Schimel., J.P. Long-term warming restructures Arctic tundra without changing net soil carbon storage. Nature 2013, 497, 615-618. [CrossRef]

41. Hobbie, S.E. Temperature and plant species control over litter decomposition in Alaskan tundra. Ecol. Monogr. 1996, 66, 503-522. [CrossRef]

42. Qian, H.F.; Joseph, R.; Zeng, N. Enhanced terrestrial carbon uptake in the Northern High Latitudes in the 21st century from the Coupled Carbon Cycle Climate Model Intercomparison Project model projections. Glob. Chang. Biol. 2010, 16, 641-656. [CrossRef]

43. Schädel, C.; Koven, C.D.; Lawrence, D.M.; Celis, G.; Garnello, A.J.; Hutchings, J.; Mauritz, M.; Natali, S.; Pegoraro, M.E.; Rodenhizer, $\mathrm{H}$; , et al. Divergent patterns of experimental and model-derived permafrost ecosystem carbon dynamics in response to Arctic warming. Environ. Res. Lett. 2018, 13, 105002. [CrossRef]

44. Schädel, C.; Mauritz, M.; Taylor, M.; Ledman, J.; Natali, S.; Schuur, E.A.G. Eight Mile Lake Research Watershed, Carbon in Permafrost Experimental Heating Research (CiPEHR): Seasonal Water Table Depth Data 2012-2018. Environ. Data Initiat. 2018. [CrossRef]

45. Laughlin, B.C. Hydrologic refugia, plants, and climate change. Glob. Chang. Biol. 2017, 23, 2941-2961. [CrossRef]

46. Meehl, G.A.; Stocker, T.F. Global Climate Projections; Cambridge University Press: Cambridge, UK, 2007.

47. Xing, W.; Bao, K.; Gallego-Sala, A.V.; Charman, D.J.; Zhang, Z.; Gao, C.; Lu, X.; Wang, G. Climate controls on carbon accumulation in peatlands of Northeast China. Quaternary Sci. Rev. 2015, 118, 78-88. [CrossRef]

48. Chaudhary, N.; Westermann, S.; Lamba, S.; Shurpali, N.; Sannel, A.B.K.; Schurgers, G.; Milleret, P.A.; Smith, B. Modelling past and future peatland carbon dynamics across the pan-Arctic. Glob. Chang. Biol. 2020, 26, 4119-4133. [CrossRef] [PubMed]

49. He, Y.; Dong, W.J.; Guo, X.Y.; Ji, J.J. Simulation of net primary productivity of terrestrial vegetation in China from 1971 to $2000 . J$. Glaciol. Geocryol. 2007, 29, 226-232. (In Chinese)

50. McGuire, A.D.; Lawrence, D.M.; Koven, C.; Clein, J.S.; Burke, E.; Chen, G.S.; Jafarov, E.; MacDougall, A.H.; Marchenko, S.D.; Nicolsky, D. Dependence of the evolution of carbon dynamics in the northern permafrost region on the trajectory of climate change. Proc. Natl. Acad. Sci. USA 2018, 115, 3882-3887. [CrossRef] [PubMed]

51. Shogren, A.J.; Zarnetske, J.P.; Abbott, B.W.; Iannucci, F.; Frei, R.J.; Griffin, N.A.; Bowden, W.B. Revealing biogeochemical signatures of Arctic landscapes with river chemistry. Sci. Rep. 2019, 9, 12894. [CrossRef]

52. Vonk, J.E.; Tank, S.E.; Walvoord, M.A. Integrating hydrology and biogeochemistry across frozen landscapes. Nat. Commun. 2019, 10, 5377. [CrossRef]

53. Yu, X.Y.; Song, C.C.; Sun, L.; Wang, X.W.; Shi, F.; Cui, Q.; Tan, W.W. Growing season methane emissions from a permafrost peatland of northeast China: Observations using open-path eddy covariance method. Atmos. Environ. 2017, 153, 135-149. [CrossRef]

54. Gao, W.F.; Yao, L.L.; Liang, H.; Song, H. Emissions of Nitrous oxide from continuous permafrost region in the Da Xingan Mountains, Northeast China. Atmos. Environ. 2019, 198, 34-45. [CrossRef]

55. Chen, S.S.; Zang, S.Y.; Sun, L. Characteristics of permafrost degradation in Northeast China and its ecological effects: A review. Sci. Cold Arid Regs. 2020, 12, 1-11.

56. Xue, Z.S.; Jiang, M.; Zhang, Z.; Wu, H.; Zhang, T. Simulating potential impacts of climate changes on distribution pattern and carbon storage function of high latitude wetland plant communities in the Xing'anling Mountains, China. Land Degrad Dev. 2021, 32, 2704-2714. [CrossRef]

57. Song, Y.Y.; Jiang, L.; Song, C.C.; Wang, X.W.; Ma, X.Y.; Zhang, H.; Tan, W.W.; Gao, J.L.; Hou, A.X. Microbial abundance and enzymatic activity from tussock and shrub soil in permafrost peatland after 6-year warming. Ecol. Indicat. 2021, 126, 107589. [CrossRef]

58. Jansson, P.E.; Moon, D.S. A coupled model of water, heat and mass transfer using object orientation to improve flexibility and functionality. Environ. Model. Softw. 2001, 16, 37-46. [CrossRef] 
59. He, H.X.; Jansson, P.E.; Gärdenäs, A. CoupModel (v6.0): An ecosystem model for coupled phosphorus, nitrogen and carbon dynamics-Evaluated against empirical data from a climatic and fertility gradient in Sweden. Geosci. Model Dev. 2020, 65, 1-55. [CrossRef]

60. Wu, S.H.; Jansson, P.E.; Kolari, P. Modeling seasonal course of carbon fluxes and evapotranspiration in response to low temperature and moisture in a boreal Scots pine ecosystem. Ecol. Model. 2011, 222, 3103-3119. [CrossRef]

61. Wu, M.S.; Ran, Y.H.; Jansson, P.E.; Chen, P.; Tan, X.; Zhang, W.X. Global parameters sensitivity analysis of modeling water, energy and carbon exchange of an arid agricultural ecosystem. Agric. For. Meteorol. 2019, 271, 295-306. [CrossRef]

62. Sun, L.; Song, C.C.; Lafleur, P.M.; Miao, Y.Q.; Wang, X.W.; Gong, C.; Qiao, T.H.; Yu, X.Y.; Tan, W.W. Wetland-atmosphere methane exchange in northeast china: A comparison of permafrost peatland and freshwater wetlands. Agric. For. Meteorol. 2018, 249, 239-249. [CrossRef]

63. Yu, X.Y.; Song, C.C.; Sun, L.; Wang, X.W.; Tan, W.W. Towards an improved utilization of eddy covariance data: Growing season $\mathrm{CO}_{2}$ exchange from a permafrost peatland in the Great Hing'an Mountains, Northeast China. Ecol. Indic. 2020, $115,106427$. [CrossRef]

64. Jansson, P.E. CoupModel: Model use, calibration, and validation. Trans. ASABE 2012, 4, 1335-1344.

65. CoupModel: Current Version of COUP Model for Download. Available online: http://www.coupmodel.com (accessed on 15 December 2021).

66. Jansson, P.E.; Karlberg, L. Coupled Heat and Masstransfer Model for Soil-Plant-Atmosphere Systems; Royal Institute of Technology: Stockholm, Sweden, 2010; p. 484.

67. Zhang, W.; Jansson, P.E.; Sigsgaard, C.; McConnell, A.; Jammet, M.M.; Westergaard-Nielsen, A.; Lund, M.; Friborg, T.; Michelsen, A.; Elberling, B.; et al. Model-data fusion to assess year-round $\mathrm{CO}_{2}$ fluxes for an arctic heath ecosystem in West Greenland $\left(69^{\circ}\right.$ N). Agric. Forest Meteorol. 2019, 272, 176-186. [CrossRef]

68. Miao, Y.Q.; Song, C.C.; Sun, L.; Wang, X.W.; Meng, H.N.; Mao, R. Growing season methane emission from a boreal peatland in the continuous permafrost zone of Northeast China: Effects of active layer depth and vegetation. Biogeosciences 2012, 9, 4455-4464. [CrossRef]

69. Chen, L.; Frauenfeld, O.W. A comprehensive evaluation of precipitation simulations over China based on CMIP5 multimodel ensemble projections. J. Geophys. Res. Atmos. 2014, 119, 5767-5786. [CrossRef]

70. Sun, Q.; Miao, C.; Duan, Q. Comparative analysis of CMIP3 and CMIP5 global climate models for simulating the daily mean, maximum, and minimum temperatures and daily precipitation over China. J. Geophys. Res-Atmos. 2015, 120, $4806-4824$. [CrossRef]

71. Haberl, H.; Erb, K.H.; Krausmann, F. Human appropriation of net primary production: Patterns, trends, and planetary boundaries. Annu. Rev. Environ. Resour. 2014, 39, 363-391. [CrossRef]

72. Peng, S.; Ciais, P.; Chevallier, F.; Peylin, P.; Cadule, P.; Sitch, S.; Li, X. Benchmarking the seasonal cycle of $\mathrm{CO}_{2}$ fluxes simulated by terrestrial ecosystem models. Glob. Biogeochem. Cycles 2015, 29, 46-64. [CrossRef]

73. $\mathrm{Mu}, \mathrm{C} . ;$ Zhang, T.; Zhao, Q.; Su, H.; Wang, S.; Cao, B.; Peng, X.; Wu, Q.; Wu, X. Permafrost affects carbon exchange and its response to experimental warming on the northern Qinghai-Tibetan Plateau. Agric. Meteorol. 2017, 247, 252-259. [CrossRef]

74. Chapin, F.S., III; Woodwell, G.M.; Randerson, J.T.; Rastetter, E.B.; Lovett, G.M.; Baldocchi, D.D.; Clark, D.A.; Harmon, M.E.; Schimel, D.S.; Valentini, R.; et al. Reconciling Carbon-cycle Concepts, Terminology, and Methods. Ecosystems 2006, 9, 1041-1050. [CrossRef]

75. Abbott, B.W.; Jones, J.B.; Edward, A.G.S.; Chapin, F.S., III; Zimov, S. Biomass offsets little or none of permafrost carbon release from soils, streams, and wildfire: An expert assessment. Environ. Res. Lett. 2016, 11, 034014. [CrossRef]

76. Kumar, D.A.; Sharma, M.P.; Tao, Y. Estimation of carbon stock for greenhouse gas emissions from hydropower reservoirs. Stoch Environ. Res Risk Assess. 2018, 32, 3183-3193. [CrossRef]

77. Keuper, F.; Dorrepaal, E.; van Bodegom, P.M.; van Logtestijn, R.; Venhuizen, G.; van Hal, J.; Aerts, R. Experimentally increased nutrient availability at the permafrost thaw front selectively enhances biomass production of deep-rooting subarctic peatland species. Glob. Chang. Biol. 2017, 23, 4257-4266. [CrossRef]

78. Finger, R.A. Effects of permafrost thaw on nitrogen availability and plant-soil interactions in a boreal Alaskan lowland. J. Ecol. 2016, 104, 1542-1554. [CrossRef]

79. Keuper, F. A frozen feast: Thawing permafrost increases plant-available nitrogen in subarctic peatlands. Glob. Chang. Biol. 2012, 18, 1998-2007. [CrossRef]

80. Wild, B. Amino acid production exceeds plant nitrogen demand in Siberian tundra. Environ. Res. Lett. 2018, 13, 034002. [CrossRef]

81. Ott, C.A.; Chimner, R.A. Long-term peat accumulation in temperate forested peatlands (Thuja occidentalis swamps) in the Great Lakes region of North America. Mires Peat. 2016, 18, 1-9.

82. Wang, H.; Richardson, C.J.; Ho, M. Dual controls on carbon loss during drought in peatlands. Nat. Clim. Chang. 2015, 5, 584-587. [CrossRef]

83. Keuper, F.; Wild, B.; Kummu, M.; Beer, C.; Blume-Werry, G.; Fontaine, S.; Gavazov, K.; Gentsch, N.; Guggenberger, G.; Hugelius, G.; et al. Carbon loss from northern circumpolar permafrost soils amplified by rhizosphere priming. Nat. Geosci. 2020, 13, 560-565. [CrossRef]

84. Zhu, K.; Chiariello, N.R.; Tobeck, T.; Fukami, T.; Field, C.B. Nonlinear, interacting responses to climate limit grassland production under global change. Proc. Natl Acad. Sci. USA 2016, 113, 10589-10594. [CrossRef] 
85. Reich, P.B. Effects of climate warming on photosynthesis in boreal tree species depend on soil moisture. Nature 2018, 562, 263-267. [CrossRef]

86. Albert, $\mathrm{K}$. Effects of elevated $\mathrm{CO}_{2}$, warming and drought episodes on plant carbon uptake in a temperate heath ecosystem are controlled by soil water status. Plant Cell Environ. 2011, 34, 1207-1222. [CrossRef] [PubMed]

87. Morgan, J.A. $\mathrm{C}_{4}$ grasses prosper as carbon dioxide eliminates desiccation in warmed semi-arid grassland. Nature 2011, 476, 202-205. [CrossRef]

88. Gregory, J.M.; Jones, C.D.; Cadule, P.; Friedlingstein, P. Quantifying carbon cycle feedbacks. J. Clim. 2009, 22, 5232-5250. [CrossRef] 